\title{
The Zooplankton Species Composition and Abundance in Ogun River, Abeokuta, Ogun State, Southwestern Nigeria
}

\section{Benjamin Onozeyi Dimowo}

Department of Aquaculture and Fisheries Management, College of Environmental Resources Management, Federal University of Agriculture, Abeokuta, Ogun state, Nigeria

$\triangle$ Corresponding author email: benjamindimowo@yahoo.com

International Journal of Aquaculture, 2013, Vol.3, No.3 doi: 10.5376/ija.2013.03.0003

Received: 9 Jan., 2013

Accepted: 29 Jan., 2013

Published: 17 Feb., 2013

Copyright (C) 2013 Dimowo. This is an open access article published under the terms of the Creative Commons Attribution License, which permits unrestricted use, distribution, and reproduction in any medium, provided the original work is properly cited.

Preferred citation for this article:

Dimowo B. O., 2013, The Zooplankton Species Composition and Abundance in Ogun River, Abeokuta, Ogun State, Southwestern Nigeria, Vol.3, No.3 8-10 (doi: 10.5376/ija.2013.03.0003)

\begin{abstract}
Investigation on the species composition and abundance of zooplankton in Ogun River, Abeokuta, Ogun state, Southwestern Nigeria was carried out for a period of seven months (December, 2011-June, 2012), Using hand trawling method, $55 \mu \mathrm{m}$ mesh size plankton net was trawled horizontally ten times to capture zooplankton. The zooplankton samples were put into properly labeled plastic containers and preserved in $4 \%$ formalin solution. A total of sixteen genera from five taxonomic groups were recorded from Ogun River. Cladocera predominated both in terms of species composition and abundance. Five species of Cladocera was recorded consisting of $31.25 \%$. Protozoa and Rotifera recorded four species each consisting of $25 \%$. Copepoda recorded two species consisting of $12.5 \%$, and Ostracoda with one species consisting of $6.25 \%$. The low nature of zooplankton abundance and species composition observed in this study must have been caused by the polluted nature of the water due to the anthropogenic activities carried out around its shores The dominance of Cladocera in this river is similar to findings from River Echara and River Imo, Southeastern Nigeria.
\end{abstract}

Keywords Abundance; Composition; Southwestern Nigeria; Ogun River; Zooplankton species

\section{Introduction}

Zooplankton (singular zooplankter) is weakly swimming microscopic animals that drift with water currents (Microsoft Corporation, 2008; Encyclopaedia Britannica, 2012). The zooplankton can be divided into two categories which includes meroplankton and holoplankton. Meroplankton (also known as temporary zooplankton) is plankton that spend only part of their lifecycle as plankton. Examples include: fish larvae, insect larvae etc. Holoplankton (also known as permanent zooplankton) is plankton that stays all their life as plankton. Examples include: crustacea, Protozoa and Rotifera. Zooplankton in association with phytoplankton makes up the planktonic food supply (Encyclopaedia Britannica, 2012). In aquaculture, small sized zooplankton e.g. rotifers etc. are often used as food stock for fish larvae. In nature, phytoplankton is fed on by zooplankton which is in turn fed on by other higher animals such as larger zooplankton, fin fish and shell fish etc. Almost all aquatic life depends on the zooplankton at least at an early stage of life. As a result of this dependence, any abrupt change in the species composition and abundance of zooplankton will affect all consumer aquatic life with problems emanating from food shortages which then lead to competition for available food, cannibalism, stress and death. The importance of the study of zooplankton hence cannot be undermined. This study is therefore aimed at investigating the species composition and abundance of Ogun River.

\section{Results}

Sixteen species belonging to five taxonomic groups were recorded from Ogun River (Table 1). Five species of Cladocera consisting of 31.25 by composition, four species each of Rotifera and Protozoa consisting of $25 \%$ by composition, two species of Copepoda consisting of $12.5 \%$ and one species of Ostracoda consisting $12.5 \%$ by composition were recorded. The abundance by group taxonomy is presented in Figure 1 and Table 2. Cladocera was the highest with $48.18 \%$ followed by Rotifera (26.07\%), Protozoa (13.86\%), Copepoda (7.92\%) and Ostracoda (3.96\%).

\section{Discussions}

The dominance of Cladocera has been observed by 
many authors among which are Ude et al. (2011) from

Echara River, Southeastern Nigeria and Ogbuagu and Ayoade (2012) from Imo River, Etche.

Table 1 Number of species in each taxonomic group of zooplankton sampled (December, 2011 - June, 2012)

\begin{tabular}{lcc}
\hline Taxonomic group & Total number of species & Percentage (\%) \\
\hline Cladocera & 5 & 31.25 \\
Rotifera & 4 & 25.00 \\
Protozoa & 4 & 25.00 \\
Copepoda & 2 & 12.50 \\
Ostracoda & 1 & 6.25 \\
Total & 16 & 100.00 \\
\hline
\end{tabular}

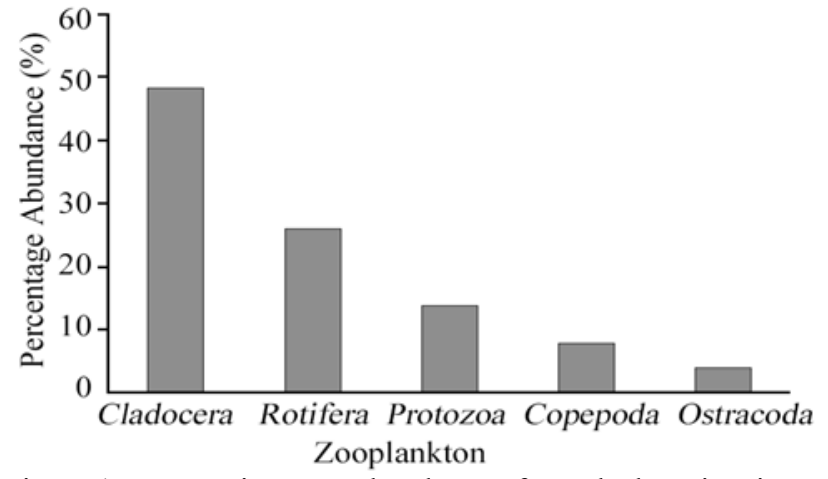

Figure 1 Taxonomic group abundance of zooplankton in River Ogun

Table 2 Abundance of zooplankton in River Ogun (December 2011 - June 2012)

\begin{tabular}{llccc}
\hline Zooplankton groups & Genus/ Species & $\begin{array}{l}\text { Genus/Species } \\
\text { Abundance (N) }\end{array}$ & $\begin{array}{l}\text { Zooplankton group } \\
\text { abundance }\end{array}$ & $\begin{array}{l}\text { Percentage zooplankton group } \\
\text { abundance (\%) }\end{array}$ \\
\hline Cladocera & Polyphemus & 33 & 146 & 48.18 \\
& Ceriodaphnia & 10 & & \\
& Scapholeberis & 35 & & \\
& Bosmina & 38 & 79 & 26.07 \\
Rotifera & Eurycerus & 30 & & \\
& Platyias & 11 & & \\
Cupelopagus & 33 & 42 & \\
Protozoa & Keratella & 23 & & \\
& Testudinella & 12 & & \\
Copepoda & Amoeba & 12 & & \\
& Oikomonas & 7 & 24 & 3.96 \\
Ostracoda & Paramecium & 15 & 12 & 100.00 \\
Total & Blepharisma & 8 & 303 & \\
\hline
\end{tabular}

The low zooplankton abundance and diversity observed in this study must have been caused by the polluted nature of the water due to the anthropogenic activities carried out around its shores. There is therefore need to regulate the amount of pollutants discharged into the river so as to avoid total ecological collapse and extinction of the populace.

\section{Materials and Methods}

\subsection{Geography of the River}

Ogun State is a state in South-western region of Nigeria. It borders Oyo and Osun states to the North, Lagos State to the South, the republic of Benin to the west and Ondo State to the east. Abeokuta is the largest city and capital of the state (NBS, 2012). River Ogun (Figure 1) is one of the main rivers in the southwestern part of Nigeria with a total area of $22.4 \mathrm{~km}^{2}$ and a fairly large flow of about $393 \mathrm{~m}^{3}$ sec $\mathrm{G}^{1}$ during the wet season (Oketola et al., 2006). It has coordinates of $3^{\circ} 28^{\prime} \mathrm{E}$ and $8^{\circ} 41^{\prime} \mathrm{N}$ from its source in Oyo state to $3^{\circ} 25^{\prime} \mathrm{E}$ and $6^{\circ} 35^{\prime} \mathrm{N}$ in Lagos where it enters the Lagos lagoon (Ayoade et al., 2004). There are two seasons in Ogun river basin, a wet season between April and October and a dry season from November to March. Mean annual rainfall ranges from $900 \mathrm{~mm}$ in the north to $2000 \mathrm{~mm}$ towards the south. The estimates of total annual potential evapo-transpiration have been put between $1600 \mathrm{~mm}$ and $1900 \mathrm{~mm}$ (Bhattacharya and Bolaji, 2010). The water is used for agriculture, transportation, human consumption, various industrial activities and domestic purposes. Along its course, it constantly receives effluents from breweries, slaughterhouses, dyeing industries, tanneries and domestic wastewater before finally discharging to Lagos lagoon (Ayoade et al., 
2004; Oketola et al., 2006). A 100 square $\mathrm{km}$ area around River Ogun has an approximate population of 3637013 (0.03637 persons per square meter) and an average elevation of 336 meters above the sea (Travel Journals, 2012). Numerous human activities such as bathing, washing of clothes, locust bean processing and transportation were noticed. Indiscriminate dumping of human excreta was observed at two of the sampling stations and this may constitute sources of pollution to the river. Four sampling stations were established and include:

\subsubsection{Station 1 (Ibẹrẹkodo)}

It is located just downwards the Ogun State Water Works Corporation at Arakanga. The water is cured by the corporation and dispensed through underground pipes to respective homes. The river here is characterized by a dam/spillway and high concrete dykes. The water is generally very clear and has good aesthetic quality. The activities here are majorly fishing, bathing, dam maintenance and fishing gear mending. No farmland was observed at this station.

\subsubsection{Station 2 (Ago ika)}

It is located close to the FADAMA III supported ferry for transportation to Lafenwa. The vegetation around the banks is very dense. The activities here includes: locust bean processing, bathing, washing of clothes and transportation by ferry. The river here is also used for refuse and human excreta disposal. The activities of the ferry men could lead to heavy siltation of the water body causing high turbidity conditions.

\subsubsection{Station 3 (Enu gada)}

It is located some few steps after the bridge connecting to Lafenwa. It is characterized by less dense vegetation and slow flowing water. Activities carried out here includes: washing of clothes, farming, indiscriminate dumping of refuse and human excreta.

\subsubsection{Station 4 (Off Pepsi bus stop)}

It is characterized by rocky outcrops with fast flowing water. The vegetation consists of terrestrial vegetation which is less dense. The water is clear and has good aesthetic quality. Activities carried out here includes: bathing, washing of clothes and drying of fishing gear on the rocks.

\subsection{Sample collection}

Zooplankton samples were collected by the hand trawling technique. This involves trawling of plankton at the littoral zone (i.e. at the shore) with $55 \mu \mathrm{m}$ mesh size plankton net horizontally. The zooplankton samples were put into properly labeled plastic containers and preserved in $4 \%$ formalin solution. This was then taken to the laboratory for analysis. In the laboratory, a drop was placed onto the glass slide of the binocular microscope and was covered with a cover slip for identification and enumeration. Zooplankton was identified at magnifications of $10 \times$, $40 \times$ and $100 \times$ using suitable keys. Enumeration of zooplankton was carried out following the drop count method adapted from Verlacar and Desai (2004) was reported as units or organisms per drop.

\section{Acknowledgement}

We thank all the members of staff especially Dr. W. O. Alegbeleye of the Department of Aquaculture and Fisheries Management, Federal University of Agriculture, Abeokuta, Ogun state, Nigeria for their collaborative spirit. We thank Mrs. Binyotubor of the National Institute of Freshwater Fisheries Research for her support. We also appreciate Mr. T. O. Dimowo for the statistical analysis.

\section{References}

Ayoade A. A., Sowunmi A. A., and Nwachukwu H. I., 2004, "Gill asymmetry in labeo ogunensis from ogun river, southwest Nigeria", Rev. Biol. Trop., 52(1): 171-175, PMid:17357414

Bhattacharya A. K., and Bolaji G. A., 2010, Fluid flow interactions in Ogun River, Nigeria, IJRRAS, 2(2): 173 - 180

Encyclopaedia Britannica, 2012, 'Zooplankton' Encyclopædia Britannica Ultimate Reference Suite, Chicago: Encyclopædia Britannica

Microsoft Corporation, 2008, 'Zooplankton' Microsoft Encarta Dictionaries

National Bureau of statistics (NBS), 2012, State Information, (www.nigerianstat.gov.ng/information/details/Ogun)

Ogbuagu D. H., and Ayoade A. A., 2012, Seasonal Dynamics in Plankton Abundance and Diversity of a Freshwater Body in Etche, Nigeria, Environment and Natural Resources Research, 2(2): 48-59

Oketola A. A., Osibanjo O., Ejelonu B. C., Oladimeji Y. B., and Damazio O. A., 2006, Water quality assessment of river ogun around the cattle market of Isheri, Nigeria, Journal of Applied Sciences, 6(3): 511-517, http://dx.doi.org/10.3923/jas.2006.511.517

Travel Journals, 2012, River Ogun, Nigeria on World map Coordinates and short facts. (www.traveljournals.net/River Ogun.htm) Retrieved 21st May, 2012

Ude E. F., Ugwu L. L. C., and Mgbenka B. O., 2011, Evaluation of Zooplankton Diversity in Echara River, Nigeria, Continental J. Biological Sciences, 4(1): 1-5

Verlacar X. N., and Desai S. R., 2004, Phytoplankton Identification manual, national institute of oceanography, Dona Paula, Goa, pp.20-21 